\title{
ANALISIS KESTABILAN MODEL PREY-PREDATOR DENGAN PEMANENAN KONSTAN PADA IKAN PREY
}

\author{
Luluk Ianatul Afifah¹, Usman Pagalay ${ }^{2}$ \\ 1,2Jurusan Matematika Fakultas Sains dan Teknologi \\ UIN Maulana Malik Ibrahim Malang \\ e-mail: $\underline{\text { lu2k.iana@yahoo.co.id }}{ }^{1}$, $\underline{\text { ssmanpagalay@yahoo.co.id }}^{2}$
}

\begin{abstract}
ABSTRAK
Model Prey-predator merupakan salah satu model interaksi antara dua spesies yang berbentuk persamaan diferensial biasa nonlinier. Tujuan dari penelitian ini yaitu untuk menganalisis model preypredator dengan pemanenan konstan pada ikan prey dan melakukan intepretasi pada model tersebut berdasarkan simulasi yang dilakukan. Dengan menggunakan nilai pemanenan $0 \leq h \leq h_{\text {maks, }}$ dimana $h_{\text {maks }}$ merupakan nilai pemanenan maksimu. Maka didapatkan lima titik kesetimbangan yang terdapat satu titik kesetimbangan yang stabil dengan jenis titik simpul dan jenis kestabilan berupa stabil asimtotik. Dari simulasi yang dilakukan dengan tiga kondisi nilai pemanenan yaitu ketika $h<h_{\text {maks }}, h=h_{\text {maks }}$ dan $h>h_{\text {maks }}$. Maka dapat disimpulkan bahwa jika nilai pemanenan melebihi nilai pemanenan maksimum maka model tersebut tidak stabil dan populasi ikan prey akan punah dan diikuti oleh populasi ikan predator. Pada penelitian selanjutnya dapat dilakukan analisis pada model prey-predator dengan memberikan perlakuan pemanenan berupa konstan pada kedua spesies dan selain itu juga dengan memberikan perlakuan pemanenan berupa fungsi pemanenan kepada salah satu spesies atau kedua spesies.
\end{abstract}

Kata Kunci: model prey-predator, pemanenan maksimum, kestabilan.

\section{ABSTRACT}

A prey-predator model is one of interaction models between the two species populations in the from system of nonlinier defferential equations. The aim of this study is to analysis a pre-predator model with harvesting at the prey and interpret the model based on simulation. The value of the harvesting used is $0 \leq$ $h \leq h_{\text {maks }}$, where $h_{\text {maks }}$ is maximum value of the Harvesting. Then there are five equilibrimu point obtained in which there is one stabile point in typenode point andthe type ofasymptotically stability. The results of the simulations, simulation done by three conditions of the harvesting is $h<h_{\text {maks }}, h=h_{\text {maks }}$ and $h>h_{\text {maks. }}$. Then we can conclude that if the value of the harvesting exceeds maximum value of the harvesting then the model was unstable and the population of prey will thet will be followed by the extinction of predator fish. Further research canbe donein a prey-predator modelwith a giventreatmentharvestingconstant to the two ofthem and what istreatment in the form of a harvesting functionfor one or two spesies.

Key Words: prey-predator model, maximum harvesting, stability.

\section{PENDAHULUAN}

Salah satu bentuk interaksi pada makhluk hidup yaitu saling memangsa antara spesies satu dengan lainnya demi kelangsungan hidupnya. Dalam matematika model tersebut dinamakan model prey-predator yang diperkenalkan oleh Vito Volterra. Pada kasus ini pemanenan yang dilakukan pada populasi ikan prey berupa konstan. Menurut [1], pemanenan yang berupa konstan pada ikan tidak mengalami kenaikan maupun penurunan disetiap tahunnya. Dalam penelitian ini diasumsikan pemanenan yang dilakukan bisa mendapatkan hasil yang maksimum.
Terdapat salah satu konsep pemanenan yaitu pemanenan maksimum disebut juga sebagai Maximum Susteinable Yield (MSY). Secara teoritis MSY merupakan jumlah tangkapan ikan predator terbesar yang dapat diambil dari persediaan suatu jenis ikan prey dalam jangka waktu yang tak terbatas.

Terdapat beberapa penelitian terdahulu mengenai kasus ini yaitu penelitian oleh [2], penelitian tersebut tentang Maximum Susteinable Yield (MSY) pada perikanan dengan struktur prey-predator, Kemudian penelitian yang dilakukan oleh [3], tentang analisis model mangsa-pemangsa Michaelis-Menten dengan pemanenan konstan pada populasi prey. Kemudian penelitian yang dilakukan oleh [4], 
tentang Effort Dynamics in a Prey-Predator Model with Herfesting. Pada penelitian tersebut membahas tentang kestabilan model preypredator dengan pemanenan yang berupa fungsi pada populasi ikan prey. Sedangkan dalam penelitian tersebut belum dibahas mengenai model prey-predator dengan pemanenan konstan. Maka penulis akan menganalisis kestabilan dan membuat simulasi dari model prey-predator dengan pemanenan konstan pada ikan prey berdasarkan model dari [4].

\section{TINJAUAN PUSTAKA}

\subsection{Model Prey-predator}

Menurut [5], model Prey-predator merupakan sistem persamaan nonlinier dan tidak ada cara yang diketahui untuk menyelsaikan secara eksplisit, meskipun demikian dimungkinkan dengan menggunakan teori kualitatif mengenai sistem semacam itu. Menurut Waluya (2006), terdapat dua kunci konsep dalam sistem nonlinier yang menentukan semua hasil dinamik. Dua konsep tersebut adalah titik kesetimbangan (titik equilibrium) dan kestabilan.

\subsection{Model Pemanenan Ikan Prey}

Menurut Verhust pada buku [6], diberikan model logistik sebagai berikut

$$
\frac{d N(t)}{d t}=r N(t)\left(1-\frac{N(t)}{K}\right)
$$

dari model pertumbuhan (2.1) dengan diberikan nilai $r=0.08$ dan nilai $\mathrm{K}=100$, maka grafik pertumbuhan maksimum dari $N(t)$ yaitu

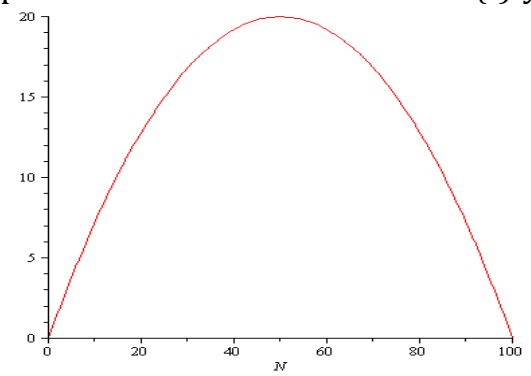

Gambar 1. Grafik Pertumbuhan Maksimum dari Persamaan (1) dengan $r=0.8$ dan $K=100$

Pada Gambar 1 bahwa terdapat dua titik kesetimbangan yaitu $N_{1}=0$ dan $N_{2}=K$. Terlihat bahwa grafik memenuhi titik kesetimbangan $N_{1}=0$, maka dapat diartikan makhluk hidup tumbuh jumlahnya tidak akan mendekati nilai nol, karena makhluk hidup tumbuh dan berkembang. Pada grafik tersebut garis menuju ke titik kesetimbangan kedua yaitu $N_{2}=K$, maka pada titik kesetimbangan kedua stabil.
Menurut [3], maka terdapat pertumbuhan populasi $N(t)$ maksimum diberi simbol $N(t)^{*}$, sesuai pada gambar (2.1), dapat dilihat nilai pertumbuhan maksimum dari populasi $N(t)$ yaitu

$$
N(t)^{*}=\frac{K}{2}
$$

sehingga populasi $N(t)$ akan mencapai nilai maksimum pada kondisi setengah dari daya dukung lingkungan.

\subsection{Linierisasi Persamaan Deferensial Biasa Autonomus}

Menurut [7], dalam suatu sistem autonomus seperti berikut:

$$
\frac{d x(t)}{d t}=f(x, y), \frac{d y(t)}{d t}=g(x, y)
$$

untuk $f$ dan $g$ adalah nonlinier, kemudian akan dicari pendekatan pada sistem linier di sekitar $\left(x^{*}, y^{*}\right)$ menggunakan deret Taylor, untuk menghilangkan suku nonliniernya sebagai berikut:

$$
\begin{gathered}
\frac{d x}{d t}=f\left(x^{*}, y^{*}\right)+\frac{\partial f}{\partial x}\left(x^{*}, y^{*}\right)\left(x-x^{*}\right)+\frac{\partial f}{\partial y}\left(x^{*}, y^{*}\right)\left(y-y^{*}\right) \\
\frac{d y}{d t}=f\left(x^{*}, y^{*}\right)+\frac{\partial g}{\partial x}\left(x^{*}, y^{*}\right)\left(x-x^{*}\right)+\frac{\partial g}{\partial y}\left(x^{*}, y^{*}\right)\left(y-y^{*}\right)(3)
\end{gathered}
$$

Misal $\quad\left(x-x^{*}\right)=v$ dan $\left(y-y^{*}\right)=u$ maka untuk $\frac{d x}{d t}=\frac{d u}{d t}$ dan $\frac{d y}{d t}=\frac{d v}{d t}$ pada keadaan setimbang $f\left(x^{*}, y^{*}\right)=0$ dan $g\left(x^{*}, y^{*}\right)=0$, kemudian disubtitusikan pada sistem persamaan (3) dan sistem persamaan linear pada titik kesetimbangan $\left(x^{*}, y^{*}\right)$ diberikan dengan

$$
\left[\begin{array}{l}
u \\
v
\end{array}\right]=\left[\begin{array}{ll}
\frac{\partial f}{\partial x} & \frac{\partial f}{\partial y} \\
\frac{\partial g}{\partial x} & \frac{\partial g}{\partial y}
\end{array}\right]
$$

dimana semua turunan parsial di dalam matriks adalah dievaluasi pada $\left(x^{*}, y^{*}\right)$ yang lebih dikel sebagai matriks Jacobi

\subsection{Titik Kestabilan Sistem Autonomous}

Menurut [8], terdapat beberapa kemungkinan dari nilai akar-akar karakteristik $\lambda_{1}$ dan $\lambda_{2}$ tersebut, maka jenis titik kesetimbangan $(0,0)$ dapat digolongkan seperti pada Tabel 1 berikut:

\subsection{Potret Fase dari Sistem Autonomous}

Menurut [5], gambar semua trayektori dari suatu sistem disebut potret fase dari sistem. Potret fase dari sebuah sistem hampir seluruhnya bergantung pada akar $\lambda_{1}$ dan $\lambda_{2}$. 
Tabel 1. Jenis-jenis Kestabilan dari Titik Kesetimbangan $(0,0)$

\begin{tabular}{|c|c|c|}
\hline $\begin{array}{l}\text { Nilai Akar- } \\
\text { akar } \\
\text { Persamaan } \\
\text { Karakteristik } \\
\end{array}$ & $\begin{array}{c}\text { Jenis dari Titik } \\
\text { Kesetimbangan } \\
(0,0)\end{array}$ & Jenis Kestabilan \\
\hline $\begin{array}{l}\text { Real, berbeda } \\
\text { dan bertanda } \\
\text { sama }\end{array}$ & $\begin{array}{l}\text { Titik simpul } \\
\text { (node) }\end{array}$ & $\begin{array}{l}\text { Stabil asimtotok } \\
\text { bila akar-akar } \\
\text { negatif, tidak } \\
\text { stabil bila akar- } \\
\text { akar positif }\end{array}$ \\
\hline $\begin{array}{l}\text { Real, berbeda } \\
\text { dan berbeda } \\
\text { tanda }\end{array}$ & $\begin{array}{l}\text { Titik plana } \\
\text { (saddle point) }\end{array}$ & Tidak stabil \\
\hline Real dan sama & $\begin{array}{l}\text { Titik bintang } \\
\text { (star) }\end{array}$ & $\begin{array}{l}\text { Stabil asimtotik } \\
\text { bila akar-akar } \\
\text { negatif, tidak } \\
\text { stabil bila akar - } \\
\text { akar positif }\end{array}$ \\
\hline $\begin{array}{l}\text { Kompleks tapi } \\
\text { tidak imajiner } \\
\text { murni }\end{array}$ & $\begin{array}{l}\text { Titik spiral } \\
\text { (spiral point) }\end{array}$ & $\begin{array}{l}\text { Stabil asimtotik } \\
\text { bila bagian real } \\
\text { dari akar-akar } \\
\text { negatif, tidak } \\
\text { stabil bila bagian } \\
\text { real dari akar- } \\
\text { akar positif } \\
\end{array}$ \\
\hline $\begin{array}{l}\text { Imajiner } \\
\text { murni }\end{array}$ & $\begin{array}{l}\text { Titik pusat } \\
\text { (center) }\end{array}$ & $\begin{array}{l}\text { Stabil, tetapi } \\
\text { tidak stabil } \\
\text { asimtotik }\end{array}$ \\
\hline
\end{tabular}

Sumber: [8]

\section{PEMBAHASAN}

\subsection{Model Prey-predator dengan Pemanenan Konstan pada Ikan prey}

Berikut diberikan diagram model preypredator dengan pemanenan konstan pada ikan prey yaitu sebagai berikut:

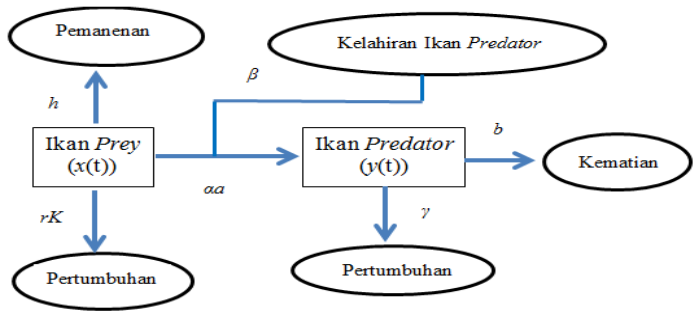

Gambar 2. Diagram Model Prey-predator dengan Pemanenan Konstan pada Ikan Prey

Pada Gambar (2) tersebut dapat dirumuskan menjadi model matematika oleh Kar dan Cakraborty (2010) sebagai berikut:

$$
\begin{aligned}
& \frac{d x(t)}{d t}=r x(t)\left(1-\frac{x(t)}{K}\right)-\frac{\alpha x(t) y(t)}{a+x(t)}-h \\
& \frac{d y(t)}{d t}=-b y(t)+\frac{\beta \alpha x(t) y(t)}{a+x(t)}-\gamma y(t)^{2}
\end{aligned}
$$

$x(t) \quad$ : Banyaknya populasi ikan prey terhadap Waktu $t$

$y(t)$ : Banyaknya populasi ikan predator terhadap waktu $t$

$r \quad: \quad$ Laju pertumbuhan interistik populasi ikan prey

$K \quad$ : Daya kapasitas populasi ikan prey

$\alpha \quad$ : Laju penangkapan relatif maksimum akibat predasi

$\beta \quad$ : Laju pertumbuhan maksimum ikan predator

$\gamma$ : Laju kematian predator akibat predasi

$A \quad$ : Laju kelahiran populasi ikan prey

$B \quad$ : Laju kematian alami ikan predator

$H \quad$ : Tingkat pemanenan ikan prey

dengan $r, K, \alpha, \beta, \gamma, a, b, h$ adalah parameter positif.

\subsection{Besaran Parameter Model}

Parameter yang dipakai dalam model prey-predator dengan pemanenan konstan pada ikan prey menggunakan parameter dari penelitian Kar dan Cakraborrty (2010), yaitu:

Tabel 2. Nilai Awal yang Digunakan untuk

\begin{tabular}{|c|c|}
\multicolumn{2}{c}{ Model } \\
\hline Vareabel & Nilai \\
\hline$x(t)$ & 80 \\
\hline$y(t)$ & 20 \\
\hline
\end{tabular}

Tabel 3. Nilai Parameter untuk Model

\begin{tabular}{|c|c|}
\hline Parameter & Nilai \\
\hline$r$ & 0.8 \\
\hline$K$ & 100 \\
\hline$\alpha$ & 0.75 \\
\hline$\beta$ & 0.75 \\
\hline$\gamma$ & 0.08 \\
\hline$a$ & 10 \\
\hline$b$ & 0.001 \\
\hline
\end{tabular}

\subsection{Penentuan Nilai Pemanenan Maksimum} (haks)

Diberikan perlakuan pemanenan berupa konstanta $h$ dalam kasus ini pada populasi ikan prey. Telah diketahui bahwa nilai pertumbuhan maksimum populasi ikan $\operatorname{prey}\left(x(t)^{*}\right)$ adalah setengah dari daya kapasitasnya $\left(\frac{K}{2}\right)$. Berdasarkan asumsi yang diberikan untuk nilai pemanenan yaitu $0 \leq h \leq$ $h_{\text {maks }}$, dimana $h_{\text {maks }}$ merupakan nilai pemanenan maksimum. Maka meneentukan nilai populasi ikan predator maksimum yaitu

$$
y(t)=\frac{-b}{\gamma}+\frac{\beta \alpha x(t)}{\gamma(a+x(t))}
$$


dengan memsubtitusikan nilai $x(t)^{*}$ pada persamaan (3.4), maka nilai populasi ikan predator maksimum yaitu

$$
y(t)=\frac{-b}{\gamma}+\frac{\beta \alpha K}{\gamma(2 a+K)}
$$

Dengan mensubtitusikan nilai populasi maksimum ikan predator $y(t)$ dan nilai pertumbuhan maksimum ikan prey $x(t)^{*}$, maka didapatkan nilai pemanenan maksimum pada populasi ikan preyh $h_{\text {maks }}$ yaitu

$$
h_{\text {maks }}=\frac{r K}{4}+\frac{\alpha b K}{\gamma(2 a+K)}-\frac{\beta \alpha^{2} K^{2}}{\gamma(2 a+K)^{2}}
$$

jika dimasukan nilai parameter sesuai tabel (3.2), maka didapatkan nilai pemanenan maksimum $h_{\text {maks }}=16.35$. maka untuk nilai pemanenan yaitu $0 \leq h \leq 16.35$.

\subsection{Analisis Model Prey-predator dengan Pemanenan Konstan pada Ikan Prey Ketika Salah Satunya Tidak Ada \\ Ketika Tidak Ada Populasi Ikan Predator}

Untuk populasi ikan prey ketika tidak adanya populasi ikan predator persamaan (4) menjadi sebagai berikut:

$$
\frac{d x(t)}{d t}=r x(t)\left(1-\frac{x(t)}{K}\right)-h
$$

dengan nilai awal sebesar $80, r=0,8, K=100$, dan $h=10$ maka didapatkan solusi dari persamaan tersebut yaitu

$$
\begin{aligned}
& x(t) \\
& =\frac{5}{1454}(20 \sqrt{727} \\
& +727 \tanh \left(\frac{1}{36350}(727 t\right. \\
& \left.\left.+50 \sqrt{727}) \operatorname{arctanh}\left(\frac{12}{727} \sqrt{727}\right)\right) \sqrt{727}\right)
\end{aligned}
$$

maka simulasi dari solusi $x(t)$ yaitu

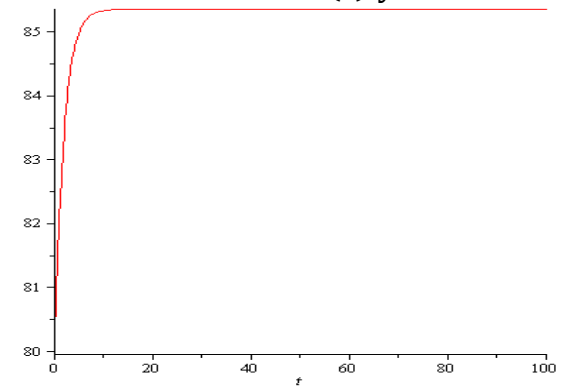

Gambar 4. Model Prey-predator dengan Pemanenan Konstan pada Ikan Prey Ketika Tidak Ada Populasi Ikan Predator

dari Gambar 4 terlihat bahwa populasi ikan prey akan mengalami peningkatan terus menerus sampai mengarah kesuatu titik yaitu 85.38 yang berati stabil dengan nilai pemanenan sebesar 10 satu satuan dan tidak dipengaruhi oleh populasi ikan predator.

\section{Ketika Tidak Ada Populasi Ikan Prey}

Untuk populasi ikan predator ketika tidak adanya populasi ikan prey, maka persamaan (3.2) menjadi sebagai berikut:

$$
\frac{d y(t)}{d t}=-b y(t)-\gamma y(t)^{2}
$$

dengan nilai awal sebesar 20, $b=10$ $\gamma=0.08$, dan $h=10$, maka didapatkan solusi dari persamaan tersebut yaitu

$$
y(t)=\frac{520}{-16000+16001 e^{\frac{1}{1000} t}}
$$

maka simulasi dari solusi $y(t)$ yaitu

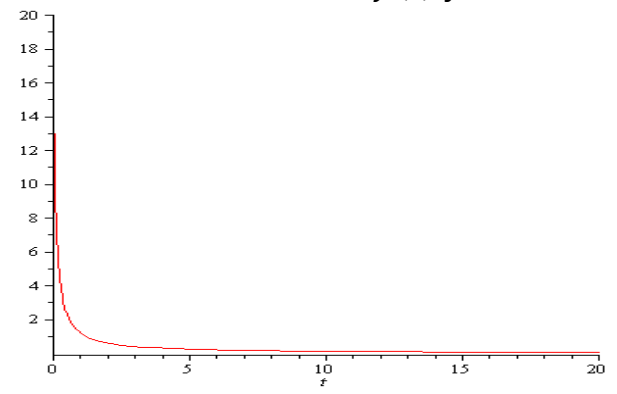

Gambar 5 Model Prey-predator dengan Pemanenan Konstan pada Ikan Prey Ketika Tidak Ada Populasi Ikan Prey

dari Gambar 5 terlihat bahwa populasi ikan predator akan mengalami penurunan terus menerus sampai menuju ke nol yang berati tidak stabil. Tidak stabil tersebut dapat diartikan bahwa jumlah populasi ikan predator mengalami penurunan sampai pada kepunahan karena tidak ada sumber makanan.

\subsection{Linierisasi Model}

maka didapatkan hasil linierisasi dari sistem tersebut dengan titik kesetimbangan $\left(x^{*}, y^{*}\right)$, yaitu

Dengan

$$
\left(\begin{array}{l}
\dot{x} \\
\dot{y}
\end{array}\right)=\left(\begin{array}{ll}
\frac{\partial f}{\partial x} & \frac{\partial f}{\partial y} \\
\frac{\partial g}{\partial x} & \frac{\partial g}{\partial y}
\end{array}\right)
$$

$\frac{\partial f}{\partial x}=r\left(1-\frac{x(t)}{K}\right)-\frac{r \cdot x(t)}{K}-\frac{\alpha \cdot y(t)}{a+x(t)}+\frac{\alpha \cdot x(t) \cdot y(t)}{(a+x(t))^{2}}$

$\frac{\partial f}{\partial y}=-\frac{\alpha \cdot x(t)}{a+x(t)}$

$\frac{\partial g}{\partial x}=\frac{\beta \cdot \alpha \cdot y(t)}{a+x(t)}+\frac{\beta \cdot \alpha \cdot x(t) \cdot y(t)}{(a+x(t))^{2}}$

$\frac{\partial g}{\partial y}=-b+\frac{\beta \cdot \alpha \cdot x(t)}{a+x(t)}-2 \cdot \gamma \cdot y$

dari Matriks Jacobi yang didapatkan, kemudiaan akan dianalisis kestabilannya.

\subsection{Penentuan Titik Kesetimbangan}

Pada persamaan (4) dan (5) dengan memisalkan $\frac{d x(t)}{d t}=0 \quad$ dan $\frac{d y(t)}{d t}=0 \quad$ maka persamaan tersebut menjadi: 


$$
\begin{gathered}
0=r x(t)\left(1-\frac{x(t)}{K}\right)-\frac{\alpha x(t) y(t)}{a+x(t)}-h \\
0=-b y(t)+\frac{\beta \alpha x(t) y(t)}{a+x(t)}-\gamma y(t)^{2}
\end{gathered}
$$

\section{Ketika $x(t)=0$}

Dengan memisalkan $x(t)=0$, maka didapatkan nilai $y(t)=0$. Maka titik kesetimbangan pertama yaitu $\left(x_{1}^{*}, y_{1}^{*}\right)=(0,0)$. Pada titik kesetimbangan ini dapat diartikan bahwa jika populasi ikan prey tidak ada maka populasi ikan predator juga tidak ada. Karena tidak ada sumber makanan untuk populasi ikan predator.

Ketika $y(t)=0$

Dengan memisalkan $y(t)=0$, maka didapatkan titik kesetimbangan yang dua dan nilai parameternya disubtitusikan maka $\left(x_{2}^{*}, y_{2}^{*}\right)=$ $\left(\frac{K+\frac{K}{r} \sqrt{r^{2}+4 \frac{r}{K} h}}{2}, 0\right)=(71.36,0)$. Untuk titik kesetimbangan yang ketiga $\left(x_{4}^{*}, y_{4}^{*}\right)=$ $\left(\frac{K-\frac{K}{r} \sqrt{r^{2}+{ }^{\frac{r}{K}} h}}{2}, 0\right)=(28.63,0) . \quad$ Pada titik kesetimbangan ini dapat diartikan bahwa jika populasi ikan predator tidak ada, maka populasi ikan prey tetap dapat bertahan hidup meskipun terdapat pemanenan pada populasi ikan prey.

\section{Ketika $x(t) \neq 0$ dan $y(t) \neq 0$}

Pertama menentukan nilai $y(t)$, yaitu

$$
y(t)=\frac{-b}{\gamma}+\frac{\beta \alpha x(t)}{\gamma(a+x(t))}
$$

kemudian smensubtitusikan nilai $y(t)$, maka persamaan (3.6)

$$
0=\left(-\frac{r x(t)^{2}}{K}\right)+r x(t)-\alpha x(t)\left(\frac{-b}{\gamma(a+x(t))}+\frac{\beta \alpha x(t)}{\gamma(a+x(t))^{2}}\right)-h
$$

Maka pada titik kesetimbangan ini, jika dimasukan nilai parameter sesuai pada tabel (3.2) dengan menggunakan bantuan software MAPLE 12 maka didapatkan dua nilai dari $x(t)$ yaitu 6.41 dan 88.33. Sehingga didapatkan dua titik kesetimbangan yaitu titik kesetimbangan keempat $\left(x_{4}^{*}, y_{4}^{*}\right)=(46.98,5.78)$ dan titik kesetimbangan kelima $\left(x_{5}^{*}, y_{5}^{*}\right)=(49.81,5.84)$. Setelah didapatkan titik kesetimbangan kemudian akan dianalisis kesetabilanya.

\subsection{Analisis Kestabilan pada Titik Kesetimbangan \\ Untuk Titik Kesetimbangan Pertama $\left(x_{1}^{*}, y_{1}^{*}\right)$}

Pada titik kesetimbangan pertama yaitu $(0,0)$, didapatkan nilai eigen sebagai berikut $\lambda=0.8$ dan $\lambda=-0.001$. Didapatkan nilai eigen real, berbeda dan tidak sama tanda yaitu maka nilai eigen pada titik kesetimbangan $(0,0)$ termasuk pada tipe titik saddle yang tidak stabil.

Untuk Titik Kesetimbangan Kedua $\left(x_{2}^{*}, y_{2}^{*}\right)$

Pada titik kesetimbangan ketiga yaitu $\left(\frac{K+\frac{K}{r} \sqrt{r^{2}+4 \frac{r}{K} h}}{2}, 0\right)=(71.36,0)$, maka didapatkan nilai eigen sebagai berikut yaitu $\lambda=-0.34$ dan $\lambda=0.49$. Didapatkan nilai eigen real, berbeda dan tidak sama tanda yaitu maka nilai eigen pada titik kesetimbangan $(71.62,0)$ termasuk pada tipe titik saddle yang tidak stabil.

Untuk Titik Kesetimbangan Ketiga $\left(x_{3}^{*}, y_{3}^{*}\right)$

Pada titik kesetimbangan keempat yaitu $\left(\frac{K-\frac{K}{r} \sqrt{r^{2}+4 \frac{r}{K} h}}{2}, 0\right)=(28.63,0)$, maka didapatkan nilai eigen sebagai berikut yaitu $\lambda=0.34$ dan $\lambda=0.41$. Didapatkan nilai eigen real, berbeda dan sama tanda yaitu maka nilai eigen pada titik kesetimbangan $(5.28,0)$ termasuk pada tipe titik simpul (node) yang tidak stabil, karena nilai eigen bertanda positif.

Untuk Titik Kesetimbangan Keempat $\left(x_{4}^{*}, y_{4}^{*}\right)$ Pada titik kesetimbangan yang kelima yaitu $(46.98,5.78)$,maka didapatkan nilai eigen yaitu $\lambda_{1}=0.022$ dan $\lambda_{2}=-0.45$. Didapatkan nilai eigen real, berbeda dan tidak sama tanda yaitu maka nilai eigen pada titik kesetimbangan $(46.98,5.78)$ termasuk pada tipe titik saddle yang tidak stabil. Ketidak stabilan disini bisa merupakan ketidak simbangan antara

\section{Untuk Titik Kesetimbangan Kelima $\left(x_{5}^{*}, y_{5}^{*}\right)$}

Pada titik kesetimbangan yang keenam yaitu(49.81,5.84), maka didapatkan nilai eigen yaitu $\lambda_{1}=-0.022$ dan $\lambda_{2}=-0.45$ didapatkan nilai eigen real, berbeda dan sama tanda, maka nilai eigen pada titik kesetimbangan $(88.33,6.30)$ termasuk pada tipe titik simpul (node) yang stabil, karena nilai eigen keduanya bertanda negatif. Maka jenis kestabilan pada titik kesetimbangan ini merupakan kestabilan asimtotik. Kestabilan pada titik kesetimbangan tersebut menunjukan bahwa, populasi ikan prey populasi ikan predator dapat hidup 
berdampingan meskipun terdapat pemanenan pada ikan prey.

\section{SIMULASI}

Kondisi Ketika $\boldsymbol{h}<\boldsymbol{h}_{\text {maks }}$

Ketika nilai pemanenan $h=0$

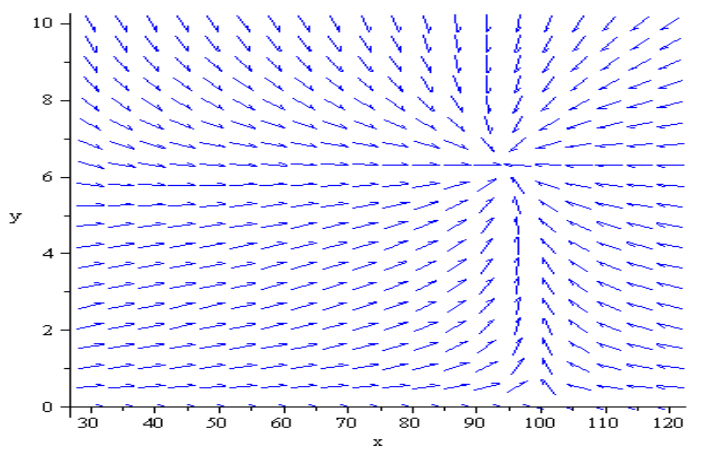

(a)

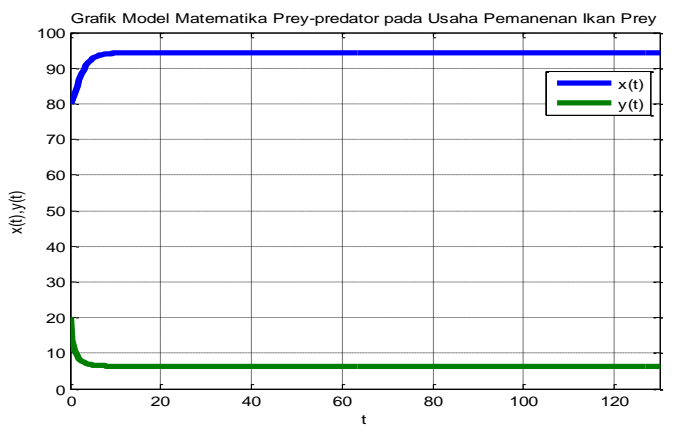

(b)

Gambar 5. Potret Fase (a) dan Grafik Perilaku (b) dari Sistem Persamaan (3.1) dan (3.2) dengan Nilai Pemanenan $h=0$

Dari Gambar 5 untuk Potret Fase (a) dapat dilihat bahwa tidak ditemukan titik kesetimbangan dengan ditunjukan adanya arah panah menuju ke suatu titik yaitu $(94.3,6.34)$. Hal ini menunjukan bahwa ketika nilai pemanenan tidak ada maka model ini stabil. Untuk grafik perilaku (b) dengan nilai pemanenan tidak ada, dapat dilihat bahwa grafik dari populasi ikan prey dengan nilai awal sebesar 80 satu satuan mengalami kenaikan pada saat waktu sebesar 12 satu satuan menuju ke suatu titik 94.3 satu satuan. Sedangkan untuk populasi ikan prey dengan nilai awal 20 satu satuan mengalami penurunan saat waktu sebesar 6 satu satuan dan menuju ke titik 6.34 satu satuan waktu. Hal ini dapat diartikan bahwa populasi ikan prey dan populasi ikan predator dapat hidup berdampingan tanpa adanya pemanenan pada populasi ikan prey.

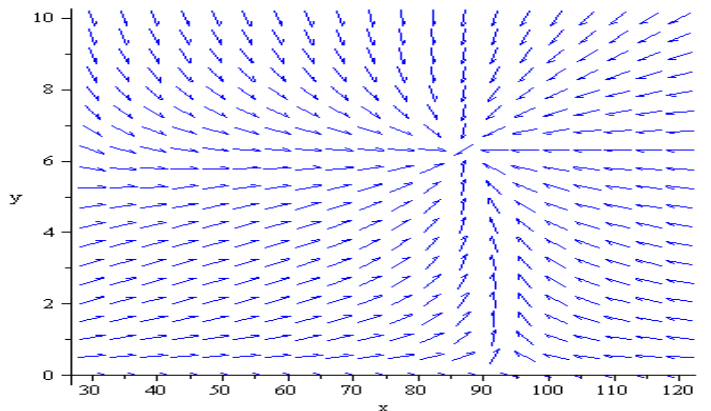

(c)

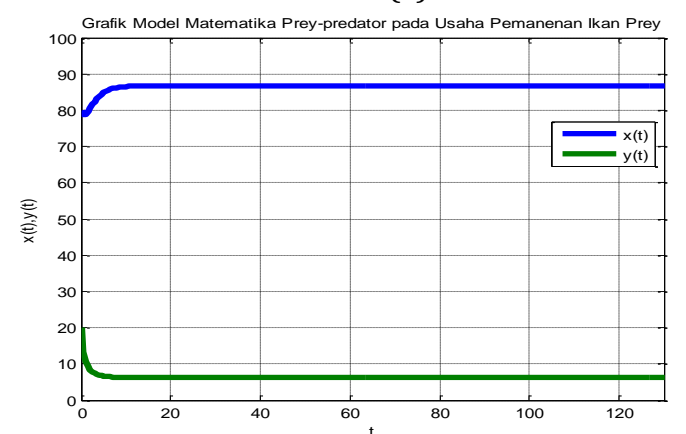

(d)

6. Potret Fase (c) dan Grafik Perilaku (d) dari Sistem Persamaan (3.1) dan (3.2) dengan Nilai Pemanenan $h=5$

Dari Gambar 6 untuk Potret Fase (c) dapat dilihat bahwa tidak ditemukan titik kesetimbangan dengan ditunjukan adanya arah panah menuju ke suatu titik yaitu $(86.7,6.29)$. Hal ini menunjukan bahwa ketika nilai pemanenan sebesar 5 satu satuan stabil. Untuk grafik perilaku (d) dengan nilai pemanenan sebesar 5 satu satuan dapat dilihat bahwa grafik dari ikan prey dengan nilai awal sebesar 80 satu satuan mengalami penurunan sebesar 78.75 satu satuan pada saat waktu 0.5 satu satuan waktu dan mengalami kenaikan menuju ke suatu titik 86.7satu satuan pada saat waktu 10 satu satuan waktu. Sedangkan untuk populasi ikan predator dengan niali awal sebesar 20 satu satuan mengalami penurunan pada saat waktu 5 satu satuan waktu dan menunju ke suatu titik 6.29 satu satuan. Hal ini dapat diartikan bahwa populasi ikan prey dan populasi ikan predator dapat hidup berdampingan meskipun adanya pemanenan pada ikan prey sebesar 5 satu satuan.Ketika

Ketika nilai pemanenan $h=16.25$

Ketika nilai pemanenan $h=5$ 


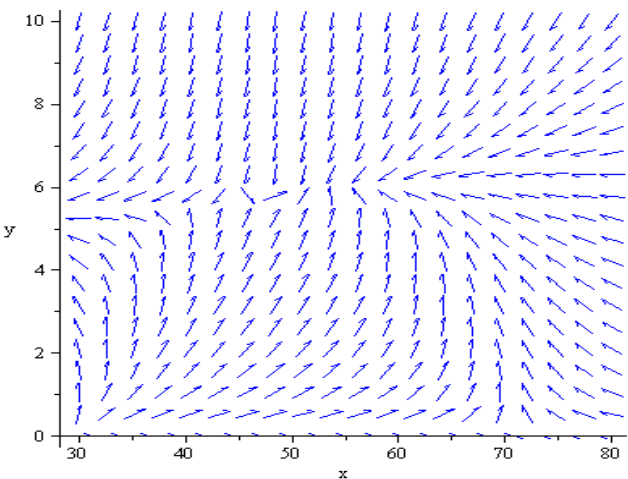

(e)

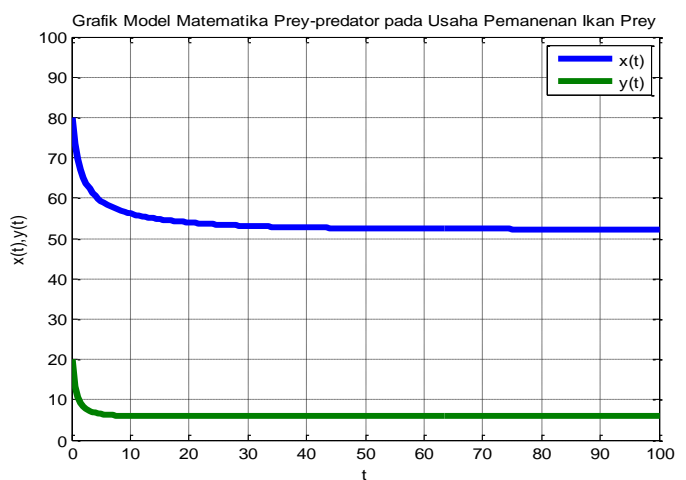

(f)

Gambar 7. Potret Fase (e) dan Grafik Perilaku (f) dari Sistem Persamaan (4) dan (5) dengan Nilai Pemanenan $h=16.25$

Dari Gambar .7 untuk Potret Fase (e) dapat dilihat bahwa tidak ditemukan titik kesetimbangan dengan ditunjukan adanya arah panah menuju ke suatu titik yaitu $(52.28,5,89)$. Hal ini menunjukan bahwa ketika nilai pemanenan sebesar 16.25 satu satuan stabil. Untuk grafik perilaku (f) dengan nilai pemanenan sebesar 16.25 satu satuan dapat dilihat bahwa grafik dari ikan prey dengan nilai awal sebesar 80 satu satuan mengalami penurunan sampai 52.28 satu satuan pada saat waktu 62 satu satuan waktu. Sedangkan untuk populasi ikan predator dengan niali awal sebesar 20 satu satuan mengalami penurunan pada saat waktu 16.5 satu satuan waktu dan menunju ke suatu titik 5,89 . Hal ini dapat diartikan bahwa populasi ikan prey dan populasi ikan predator dapat hidup berdampingan dengan meskipun adanya pemanenan pada ikan prey sebesar 16.25 satu satuan.

Kondisi Ketika $h=h_{\text {maks }}$

Ketika nilai pemanenan $h=16.35$

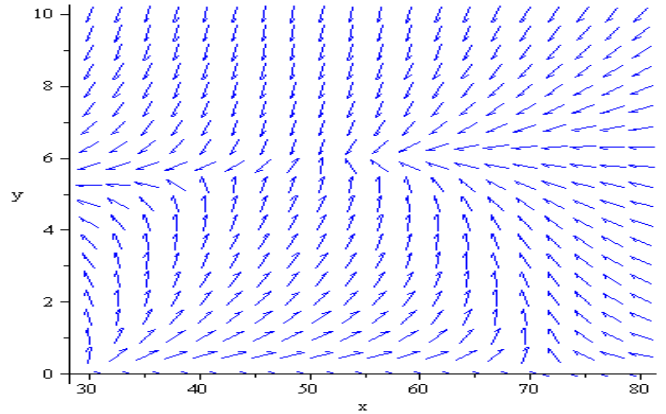

(g)

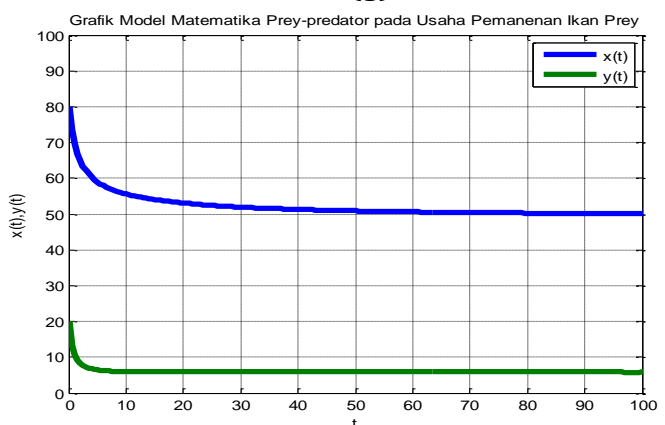

(h)

Gambar 8. Potret Fase (g) dan Grafik Perilaku (h) dari Sistem Persamaan (4) dan (5) dengan Nilai Pemanenan $h=16.35$

Dari Gambar 8. untuk Potret Fase (g) dapat dilihat bahwa tidak ditemukan titik kesetimbangan dengan ditunjukan adanya arah panah menuju ke suatu titik yaitu $(49.81,5.84)$. Hal ini menunjukan bahwa ketika nilai pemanenan sebesar 16.35 satu satuan stabil. Untuk grafik perilaku (h) dengan nilai pemanenan sebesar 16.35 satu satuan dapat dilihat bahwa grafik dari ikan prey dengan nilai awal sebesar 80 satu satuan mengalami penurunan sampai 49.81 satu satuan pada saat waktu 40 satu satuan waktu. Sedangkan untuk populasi ikan predator dengan niali awal sebesar 10 satu satuan mengalami penurunan pada saat waktu 10 satu satuan waktu dan menunju ke suatu titik 5.84 satu satuan. Hal ini dapat diartikan bahwa populasi ikan prey dan populasi ikan predator dapat hidup berdampingan dengan meskipun adanya pemanenan pada ikan prey sebesar 16.35 satu satuan.

Kondisi Ketika $\boldsymbol{h}>\boldsymbol{h}_{\text {maks }}$

Ketika nilai pemanenan $h=16.45$ 


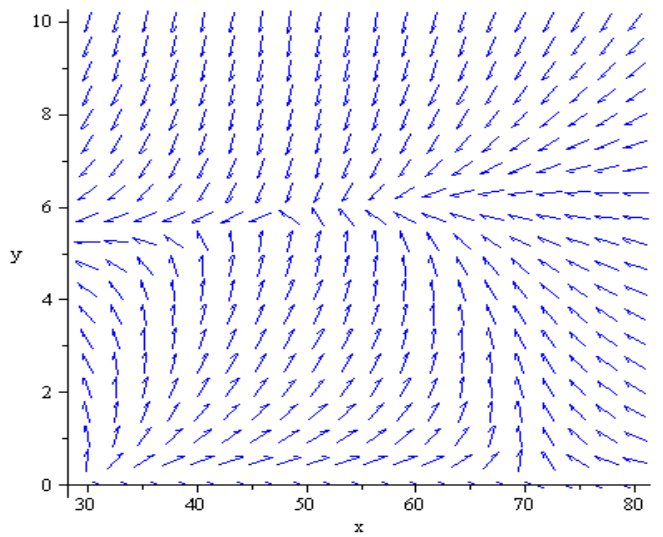

(i)

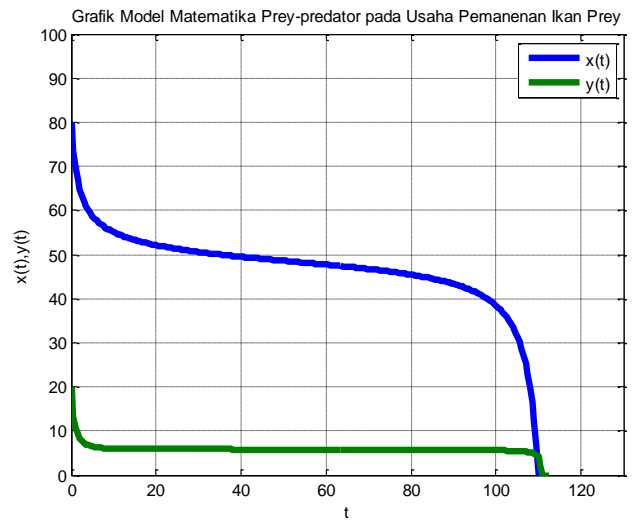

(j)

Gambar 9. Potret Fase (i) dan Grafik Perilaku (j) dari Sistem Persamaan (4) dan (5) dengan Nilai Pemanenan $h=16.45$

Dari Gambar 9. untuk Potret Fase (i) dapat dilihat bahwa tidak ditemukan titik kesetimbangan dengan ditunjukan tidak adanya arah panah menuju ke suatu titik. Hal ini menunjukan bahwa ketika nilai pemanenan sebesar 16.45 satu satuan tidak stabil. Untuk grafik perilaku (j) dengan nilai pemanenan sebesar 16.45 satu satuan dapat dilihat bahwa grafik dari ikan prey dengan nilai awal sebesar 80 satu satuan mengalami penurunan sampai 0 satu satuan pada saat waktu sebesar 110 satu satuan waktu. Sedangkan untuk populasi ikan predator dengan niali awal sebesar 20 satu satuan mengalami penurunan sampai 0 satu satuan pada saat waktu sebesar 111 satu satuan waktu. Hal ini dapat diartikan bahwa populasi ikan prey akan mengami kepunahan kemudian terjadi kepunahan pada populasi ikan predator karena terdapat pemanenan sebesar 16.45 satu satuan.

Ketika nilai pemanenan $h=18$

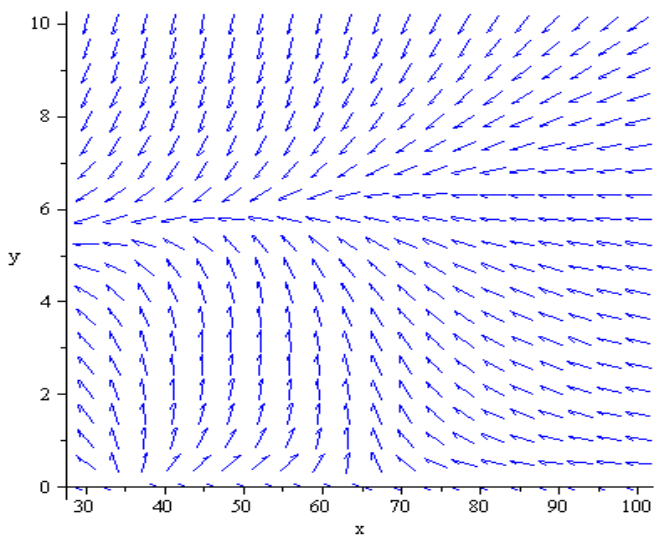

(k)

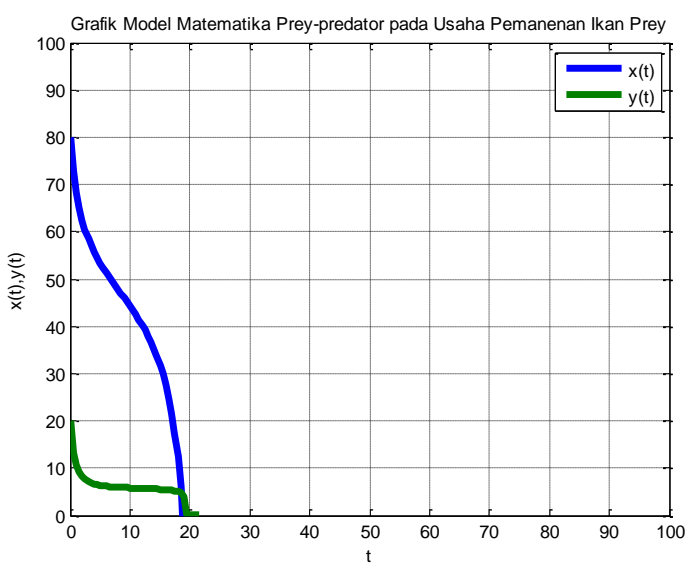

(l)

Gambar 10. Potret Fase (m) dan Grafik Perilaku

(n) dari Sistem Persamaan (4) dan (5) dengan Nilai Pemanenan $h=18$

Dari Gambar 10. untuk Potret Fase (k) dapat dilihat bahwa tidak ditemukan titik kesetimbangan dengan ditunjukan tidak adanya arah panah menuju ke suatu titik. Hal ini menunjukan bahwa ketika nilai pemanenan sebesar 18 satu satuan tidak stabil. Untuk grafik perilaku (l) dengan nilai pemanenan sebesar 18 satu satuan dapat dilihat bahwa grafik dari ikan prey dengan nilai awal sebesar 80 satu satuan mengalami penurunan sampai 0 satu satuan pada saat waktu sebesar 19 satu satuan waktu. Sedangkan untuk populasi ikan predator dengan niali awal sebesar 20 satu satuan mengalami penurunan sampai 0 satu satuan pada saat waktu sebesar 20 satu satuan waktu. Hal ini dapat diartikan bahwa populasi ikan prey akan mengami kepunahan kemudian terjadi kepunahan pada populasi ikan predator karena terdapat pemanenan sebesar 18 satu satuan.

\section{PENUTUP}

\section{KESIMPULAN}

Berdasarkan penelitian yang dilakukan pada model prey-predator dengan pemanenan konstan pada ikan prey. Dari hasil analisis yang 
dilakukan pada model tersebut, didapatkan nilai pemanenan maksimum $h_{\text {maks }}$ sebesar 16.35 satu satuan. Kemudian dilakukan analisi kestabilan ketika nilai pemanen maksimum. Dari lima titik kesetimbangan didapatkan satu titik kesetimbangan yang stabil yaitu pada titik (49.81,5.84) kemudian didapatkan nilai eigennya yaitu $\lambda_{1}=-0.022$ dan $\lambda_{2}=-0.45$, maka jenis titik kesetimbangan yaitu berupa titik simpul yang stabil dengan jenis kestabilan stabil asimtotik.

Dari simulasi yang dilakukan dengan nilai pemanenan diasumsikan $0 \leq h \leq h_{\text {maks }}$, maka diberikan tiga kondisi untuk menganalisi model ini yaitu kondisi pertama $h<h_{\text {maks }}$, kondisi kedua $h=h_{\text {maks }}$, dan kondisi ketiga $h>h_{\text {maks }}$. Pada kondisi nilai pemanenan $h<$ $h_{\text {maks }}$ dan $h=h_{\text {maks }}$ dapat disimpulkan model tersebut stabil, ini berarti bahwa spesies ikan prey dan populasi ikan predator dapat hidup berdampingan meskipun terdapat pemanenan pada populasi ikan prey. Pada kondisi nilai pemanenan $h>h_{\text {maks }}$ dapat disimpukan bahwa model tersebut tidak stabil, ini berarti populasi ikan prey dan populasi iakn predator tidak dapat hidup berdampingan dengan nilai pemanenan melebihi nilai pemanenan maksimu.

\subsection{Saran}

Pada penelitian selanjutnya dapat dilakukan pada model prey-predator dengan memberikan perlakuan pemanenan berupa konstan pada kedua spesies dan selain itu juga dengan memberikan perlakuan pemanenan berupa fungsi pemanenan kepada salah satu spesies atau kedua spesies.

\section{DAFTAR PUSTAKA}

[1] Idels, W dan Mai, W, Harvesting Fisheries Menegement Strategis With Modified Effort Function, IJMC Jurnal dalam Modeling Complex System, 2006.

[2] Hertini, E dan Gusriani, N, Maximum Sustainable Yield (MSY) pada Perikanan dengan Struktur Prey-predator, Sumedang: Universitas Padjadjaran, 2013.

[3] H. Dwaradi, Analisis Model Mangsapemangsa Michaelis-menten dengan Pemanenan pada Populasi Mangsa,
Skripsi S1 tidak dipublikasikan. Bogor:

ITB, 2011

[4] Kar,T dan Cakraborty, K, Effort Dynamics In A Prey-predator Model With Harvesting. Vol.6 No. 3 Hal. 318-332, India, 2010.

[5] Finizio dan Ladas, Persamaan Deferensial Biasa dan Dan Penerapan Moderen, Jakarta: Eirlangga, 988.

[6] R. J. Iswanto, Pemodelan Matematika: Aplikasi dan Terapan, Yogyakarta: Graha IImu, 2012.

[7] Boyce, W. E dan Prima, R. C, Elementery Differential Equation and Boundary Value Problem, Uited States of America: John Wiley and Sons, 1997.

[8] Widowati dan Sutimin, Buku Ajar Model Matematika, Semarang: Fakultas MIPA UNDIP, 2007.

[9] Kartono, Persamaan Deferensial Biasa: Model Matematika Fenomena Perubahan, Yogyakarta: Graha Ilmu, 2012.

[10] P. S. Redjeki, Diktat Kuliah Ma2271 Metoda Matematika, Bandung: Fakultas MIPA ITB, 2009.

[11] R. C. Robinson, An Introduction to Dynamical System Continous and Discrete, New Jersey: Pearson Education, In, 2004. 